\section{Son of Rimmon}

One of two "sons of Rimmon" who murdered Ishbosheth, Saul's son, while he slept, then took the head of Ishbosheth to David expecting a reward (2 Sam 4:2-12). In the narrative, David reacts with outrage that these men killed an innocent man in his own house and orders them executed and their hands and feet publicly displayed. Though David benefits from Ishbosheth's death, the narrative stresses David's distance from the murder of his rival in ways similar to the report of Saul and Jonathan's death in 2 Sam $1: 1-16$.

Scholars debate why Baanah and his brother killed Ishbosheth. For some, the identification of their father as Rimmon the Beerothite hints that the brothers are motivated by a long-standing feud between Saul's family and the Gibeonites, since Beeroth is identified as one of four Gibeonite cities in Josh 9:17 and the Gibeonites later demand retaliation against Saul's family in 2 Sam 21:1-9. Others assert that the identification "Beerothite" is simply geographical in 2 Sam $4: 2$ and that Rimmon was a Benjaminite who lived in Beeroth. In this case, Baanah and his brother kill Ishbosheth in order to gain David's favor and a reward. In retelling this story, Josephus states explicitly that they hoped to receive great gifts from David and believed he would accept their deed favorably and offer them security (Ant. 7.46-52).

\section{Of Netophah}

Baanah was the father of Heleb, one of David's 30 military heroes (2 Sam 23:29; Heled in $1 \mathrm{Chr}$ $11: 30)$. In 1 Chr David's champions appear in a list of David's supporters at his coronation.

\section{Returnee from Exile}

Baanah was one of 11 (Ezra 2:2) or 12 (Neh 7:7) leaders of the gôlâ who, according to Neh $7: 5$, are among those who returned first.

\section{Contemporary of Nehemiah}

Baanah was a leader who pledged in writing to observe the law of Moses (Neh 10:28).

Bibliography: - Begg, C., "The Assassination of Ishbosheth According to Josephus,” Anton. 73/2 (1998) 241-53. - McCarter, P. K., II Samuel (Anchor Bible 9; Garden City, N.Y. 1984).

Janell A. Johnson

\section{Baara}

In the Chronicler's extended list of descendants of Benjamin, Baara (Heb. Ba ă $r \bar{a}^{\prime}$; Gk. B $\alpha \alpha \varrho \alpha, B \alpha \alpha \delta \alpha$ ) and Hushim are listed as wives sent away by their husband Shaharaim (1 Chr $8: 8)$. There is no reason given for their divorce. One might speculate that Shaharaim divorced Baara because she was barren, since there are no children listed for her in the text. Yet Hushim is also sent away, and she is listed as the mother of two sons of Shaharaim. A third wife, Hodesh, is listed as the mother of seven other sons.

Baara and Hushim are dismissed before Shaharaim moves to Moab, and he has other sons there. Shaharaim becomes the ancestor of Benjaminites living in Moab.

Bibliography: - Klein, R. W., 1 Chronicles (Hermeneia; Minneapolis, Minn. 2006).

Elna K. Solvang

\section{Baaseiah}

Baaseiah (MT Ba'ăśeyâ; LXX M $\alpha \alpha \sigma \iota \alpha)$ son of Malchijah was a Levite and ancestor of Asaph the musician. Baaseiah receives only one biblical citation, which occurs in the genealogy list of $1 \mathrm{Chr} 6: 40$ [MT 6:25].

The name Baaseiah contains a possible beth $/ \mathrm{mem}$ confusion in the Masoretic Text. One could, based on the manuscript evidence of $\mathrm{LXX}^{\mathrm{BL}}$ and Syr, read the name as Maaseiah. This personal name, meaning "Work [i.e., Creation] of YHWH," was a common biblical appellation.

Bibliography: - Klein, R., 1 Chronicles (Hermeneia; Minneapolis, Minn. 2006).

Daniel D. Pioske

\section{Baasha}

Baasha (MT Ba $a^{\complement} \breve{a} \bar{a}^{3}$; LXX B $\left.\alpha \alpha \sigma \alpha\right)$ occurs in the HB/ OT as the name of a king who ruled in Israel at the end of the 10th and the beginning of the 9th century BCE. The name, which is also attested for a Moabite king and an Ammonite dignitary (Rendsburg), is a short form of either "Baal hears" or "Baal of heaven." The negative presentation of his reign in $1 \mathrm{Kgs} 15: 33-16: 7$ is the work of several Deuteronomistic redactors (Sweeney: 197-98), so that it is very difficult to reconstruct the historical context of his long reign. For the Deuteronomists, the central event of Baasha's rule (between approximately 910$887 \mathrm{BCE}$ ) was an oracle of doom that the prophet Jehu son of Hanani delivered against him (1 Kgs $16: 1-4$ and 7 [the latter verse is clearly a more recent addition]) and his house. The Deuteronomists structured the oracle in 16:1-4 very similarly to those against Jeroboam (1 Kgs $14: 1-8)$ and Ahab (1 Kgs 21:21-24; 2 Kgs 9:8-10, mentioning Baasha explicitly). Apparently they considered Baasha as one of the worst rulers of the northern kingdom, probably because he was at war against the Judean king Asa, who is presented in the Deuteronomistic History as a quite positive figure (1 Kgs 15:16-22; see also 1 Chr $16: 1-8)$.

Even if the historical reconstruction of Baasha's reign remains hypothetical, it is plausible that the 
later redactors had at their disposal Judahite and perhaps also Israelite chronicles on which they drew (Na'aman). Baasha was an usurper since he assassinated Jeroboam's son, Nadab, and all his other descendants $(15: 27-30)$. The murder happened during the siege of the Philistine town Gibbethon (Ras Abu Hamid, $5 \mathrm{~km}$ northwest of Gezer). This may indicate that Baasha, from the tribe of Issachar, was an officer or general of Nadab's army and that his coup was supported by the troop. For the Deuteronomists, Baasha's assassination of Nadab was the fulfillment of a prophetic oracle against Jeroboam (15:29-30) accusing him of his cultic sins (the establishment of YHWH sanctuaries in Bethel and Dan). According to Miller and Hayes, Baasha was first supported by the prophet Jehu, but once in power was denounced by him (278). It is not sure however, whether the oracle in 16:1-4 contains historical information. Apparently Baasha wanted to express the establishment of a new dynasty by transferring its seat to Tirzah (probably Tell al Far'a, about $8 \mathrm{~km}$ northeast of Shechem); according to the MT of $1 \mathrm{Kgs} 14: 17$, Tirzah seems to have already been the capital under Jeroboam, but this is a late gloss which is not supported by the Septuagint (see LXX 12:24n). Baasha fortified the borders of his kingdom by building Ramah (15:17); he was apparently able to dominate Judah (see also Jer 41 : 9) so that Asa had to seek support from the Arameans. The Deuteronomists speak of Baasha's "power" or "strength" (gěbûrâ; 1 Kgs 16:5) without specifying his exploits. Even if they abhorred this king, they had to acknowledge that he succeeded in stabilizing his power for more than two decades.

Bibliography: - Miller, J. M./J. H. Hayes, A History of Ancient Israel and Judah (Louisville, Ky./London 22006). - Na'aman, N., "The Northern Kingdom in the Late Tenth-Ninth Centuries BCE," Proceedings of the British Academy 143 (2007) 399418. - Rendsburg, G. A., "Baasha of Ammon," JANES 20 (1991) 57-61. - Sweeney, M. A., First and Second Kings (OTL; Louisville, Ky./London 2007). - Würthwein, E., Die Bücher der Könige: 1 Könige 1-16 (ATD 11/1; Göttingen 1977).

Thomas Römer

\section{Bab Edh-Dhra}

A major archaeological site on the Jordanian side of the Dead Sea Valley, located west of Karak on the eastern side of the Lisan peninsula. Inspired by earlier exploration and research (including that of Paul W. Lapp), Walter E. Rast and R. Thomas Schaub organized the expedition to the Dead Sea Plain. Between 1973 and 1981, this team excavated Bab edhDhra $^{c}$ for four seasons and conducted regional archaeological survey.

The extensive cemetery yielded significant pottery, other artifacts, and skeletal remains from various types of burials-tumuli, charnel houses, and shaft tombs. Between the Early Bronze Age IB and III, Bab edh-Dhra' evolved into a substantial walled town. The Rast and Schaub team gave considerable attention to the study of plant remains and trade connections with neighboring regions.

While this multidisciplinary research program has contributed much to the knowledge of Early Bronze Age cultural development, the possible connection between Bab edh-Dhra ${ }^{c}$ and Hebrew traditions is especially intriguing. During their regional survey, Rast and Schaub found additional Early Bronze Age sites in the Ghor, south and southeast of the Dead Sea (e.g., the sites of Numeira, Safi, Feifa, and Khanazir). Work continues in the region. Meanwhile, excavations were completed at $\mathrm{Nu}-$ meira, located south of Bab edh-Dhrac, and some scholars have suggested that the demise of these two sites gave rise to the Genesis accounts of Sodom and Gomorrah. Indeed, some scholars connected the five Early Bronze Age sites mentioned above with the five "cities of the plain" mentioned in Genesis 14 (i.e., Sodom, Gomorrah, Admah, Zeboiim, and Bela/Zoar). This facile leap has chronological problems, since settlement at Bab edh-Dhrac and Numeira ended centuries earlier than most scholars would date Abraham.

Bibliography: - Rast, W. E./R.T. Schaub (eds.), Bab edhDhra': Excavations at the Town Site (1975-1981), 2 vols. (Winona Lake, Ind. 1989). - Schaub, R. T./W.E. Rast, Bab edh-Dhrac: Excavations in the Cemetery Directed by Paul Lapp (Winona Lake, Ind. 1989). - Schaub, R. T., "Bab edh-Dhra'," The New Encyclopedia of Archaeological Excavations in the Holy Land 1 (New York 1993) 130-36.

Gerald Lee Mattingly

\section{Babai the Great}

Babai the Great (550/555-ca. $628 \mathrm{CE})$, the third abbot of the Great Monastery at Izla, was an important figure in the monastic life of the "Church of the East." He even led the church during a 20-year vacancy of the patriarchal see. Of the more than 80 works ascribed to him, some 10 are still extant. Of these, a systematic Christology called the "Liber de Unione" and the commentary on the "Gnostic chapters" of Evagrius Pontikus can be considered his major works.

On the one hand Babai is important because he developed the first systematic presentation of the diphysite christology of his church, which centred on the precise distinction between the godhead and mankind. The exhortation in the epistle to the Philippians with the juxtaposition of the form of God and the form of a servant served him as a hermeneutic key. In this way he could also interpret John $1: 14$ as the temporal incarnation of the flesh within which dwelt the immutable word.

Based on Evagrius, Babai also developed a mystical-ascetic theology within which he described the momentary unification of God and man during genuine prayer. Here he referred to St. Paul's sermon of knowing God as though looking in a mirror 